\title{
Development of Fortified Laddoo with Sweet Lupine
}

\author{
Maria T. S. Al-Zahrani \\ Professor of Nutrition and Food Science, \\ Department of Family Education, Umm-Al-Qura University, \\ Kingdom of Saudi Arabia
}

\begin{abstract}
Laddoo is a traditional sweet and well-accepted by people. Traditional (wheat) laddoo had contained only sugar and saturated fatty acids, which are not very healthy. Addition of sweet lupine powder at different levels at 25.0, $50.0,75.0$ and $100 \%$, respectively caused an increase in all measured chemical parameters, except for carbohydrates. In addition, it could be noticed that when the sweet lupine powder was caused the vitamins were increasing. Moreover, the minerals content was increased especially calcium, magnesium, iron zinc, and potassium. Sweet lupine laddoo is a nutritionally enhanced and sensory acceptable snack in comparison to $100 \%$ flour laddoo. The addition of sweet lupine flour produces a high protein mineral-rich laddoos with a decent texture. These laddoos are healthy more available providing considerably additional fiber, protein, and minerals than traditional laddoos, however with the comparable appearance and high satisfactoriness ratings. Consuming fortified laddoos could provide males and females with part of their daily requirements of protein, dietary fiber, vitamins, calcium, iron, and zinc.

From the obviously results it could be recommended that the addition of sweet lupine until $75 \%$ to give laddoo is nutritionally and acceptable in comparison to $100 \%$ wheat flour laddoo.
\end{abstract}

Keywords: Wheat Flour, Sweet Lupine, Laddoo, Sensory evaluation, Nutrition.

\section{INTRODUCTION}

Mixtures of cereals and legumes are leading to products rich in protein with great biological value and also, legumes are reduced in sulfurous amino acids and high content in lysine. On the other hand, cereals are a decrease in lysine and an increase in sulfurous amino acids. Thus, cereals and legumes are complementary contribution characteristics in the nutritional quality (Teba et al., 2009).

Lupine (Lupinus spp.) is a legume that has contained and various nutritional constituents. Meanwhile, lupine is not extensively utilized in human food which may be caused to the presence of anti-nutritional agents that should be isolated before consumption of this legume (Botaro, 2010 and Monteiro et al., 2010). Lupinus albus varieties underwent the action of modifying over time to remove the anti-nutritional agents and alkaloids. The heat is one of the major methods utilized to separate these antinutritional agents, and various techniques of heat use, like extrusion, roasting, steaming and microwaving, can be applied (Botaro, 2010 and Monteiro et al., 2010).

Sirtori et al. (2004) found that the research work has demonstrated that consumption of lupin-based foods leads to a lowering in low-density lipoprotein cholesterol levels. Other work has proved sweet lupine to reduce to reduce lipid parameters (Arnoldi, 2008) and blood pressure (Lee et al., 2009). The fortification lupin fiber to the diet supplies appropriate variation in serum lipids. This may be incoming component is beneficial in the lowering of cardiovascular disease (Hall et al., 2005). Diaz et al. (2017) reported that it is possible to produce corn-based extrudates containing up to $20 \%$ sweet lupine without any substantial changes in sectional expansion and stiffness. Wandersleben et al. (2018) reported that $90 \%$ of the individuals to like and like extremely sweet lupine supplemented bread.

Laddu or laddoo or Avinsh (laddẹ, $\quad l \bar{a} d \underline{u} \bar{u})$ is a sphere-shaped sweet originating from the Indian subcontinent; the name originated from the Sanskrit word Lattika. Laddoos are made of flour, fat (ghee/butter/oil), and sugar, with other ingredients that vary by recipe, like chopped nuts or dried raisins. They are often served at festive or religious occasions ("Sweet shops make hay in Diwali shine", 2019).

Laddoo is a traditional, energy dense, ball-shaped sweet enjoyed by people of all age groups. Laddoos are made with variety of local ingredients. The basic ingredient of laddoo is either wheat flour or chickpea flour. The product provides good amounts of biological proteins, functional property, vitamins, minerals and adequate fiber and has a good satiety value (Naidu et al., 2013). Flours utilized for laddoo had contained chickpea flour, wheat semolina, and ground coconut (Baker, 2006). Research has been achieved to add different flours like soy flour (Ghatge, 2013), more grain flour (Naidu et al., 2013 and Verma et al., 2014) others (Chetana, 2004) incorporated synthetic sweeteners like sorbitol and mannitol in the preparation of laddoos.

The target of this study was to produce formulate a nutritious laddoo utilizing sweet lupine and to evaluate its nutritional, functional, textural and sensory properties of the product.

\section{Materials}

\section{MATERIALS AND METHODS}

Sweet lupine seeds (Lupinus albus) were obtained from local market in Saudi Arabia.

Sweet lupine seeds were soaked in water for $48 \mathrm{~h}$ with several changes of water then the soaked seeds were airdried for 3 days at room temperature $\left(25^{\circ} \mathrm{C} \pm 2\right)$. The dried seeds were milled in laboratory to pass through a 60 -mesh sieve.

Wheat flour (Traticum astivum) $72 \%$ extraction, sugar, milk, baking powder, orange powder, coconut 
powder and ghee were obtained from the local market in Saudi Arabia.

\section{Methods}

\section{Preparation of laddoo formulae}

Wheat flour $72 \%$ extraction (500 gram) was used for laddoo fortified with sweet lupine flour at different levels 25.0, 50, 75.0 and $100 \%$, respectively. These are combined separately with sugar (300 gram), milk (100 ml), baking powder (10.0 gram) and orange powder (50.0 gram) as a flavoring and color in additional coconut powder $(50.0$ g) as a taste well as it was cooked in ghee and molded into a ball shape.

\section{Sensory evaluation of laddoo products}

The sensory evaluation was carried out in order to get consumer response for overall acceptability of the $25 \%$, $50.0 \%, 75.0 \%$ and $100 \%$ sweet lupine flour incorporated laddoo compared to the control laddoo. Sensory evaluation was achieved by 20 professional panelists. It was done by scoring the test for the different characteristics on which the product was rated are color, appearance, aroma, hardness, flavor, mouthfeel, aftertaste and overall acceptability. For each sample, the professional panelists scored their liking of these characteristics using the ninepoint Hedonic scale. The scores represented the following: 1 = dislike extremely, $2=$ dislike very much, $3=$ dislike moderately, $4=$ dislike slightly, $5=$ neither like nor dislike, 6=like slightly, 7=like moderately, 8=like very much and 9=like extremely (Ghavidel and Prakash, 2007). An average of ten scores for each parameter is reported.

\section{Chemical analysis of raw materials and their laddoo products}

Sweet lupine, wheat flour and their different products laddoo were determined the chemical composition as moisture, ash, protein and fat according to the standard AACC (2000) methods. Nitrogen content as estimated by Micro-Kjeldhal method and was converted to protein by using a factor of 6.25. Carbohydrates are determined by difference. Total calories were calculated by the formula of James (1995) as the equation follows:

Total calories $=$ Fat $\times 9+$ Protein $\times 4+$ Total carbohydrate $\mathrm{x} 4$

\section{Determination of total carotenoids and vitamins}

Total carotenoids were determined in raw materials and their different products laddoo using the method outlined by Santra et al. (2003). A calibration curve was made from known quantities of $\beta$-carotene and was expressed as $\mathrm{mg} / \mathrm{kg}$ on dry weight basis.

Vitamins content: vitamin $\mathrm{E}$, vitamin $\mathrm{A}$ and vitamin $\mathrm{B}$ group $\left(\mathrm{B}_{1}, \mathrm{~B}_{2}, \mathrm{~B}_{3}, \mathrm{~B}_{6}\right.$, and $\left.\mathrm{B}_{9}\right)$ were determined according to the methods described by Pyka and Sliwiok (2001), Noll (1996) and Batifoulier et al. (2005) respectively.

\section{Determination of minerals content}

Minerals content were determined in the diluted solution of ash raw materials and their different products laddoo using the atomic absorption spectrophotometer (3300 Perkin-Elme) as described in by AOAC (2012).

\section{Statistical analysis}

Statistical analyses were carried out by SPSS 16 program. Data were expressed as means \pm SEM and the Statistical analysis was performed using one-way analysis of variance followed by Duncan's tests. (SPSS, 2000).

\section{RESULTS AND DISCUSSION}

\section{Sensory evaluation of laddoo products}

The data pertaining to the effect of incorporation of various levels of sweet lupine flour (25.0, 50.0, 75.0 and $100.0 \%$ )on sensory attributes of laddoo and the results have been shown in Table (1). Sweet lupine laddoo was evaluated for sensory attributes like color and appearance, taste, texture, mouthfeel and overall acceptability.

The scores obtained for all sensory attributes of $75 \%$ sweet lupine laddoo were significantly higher than control. The flavor of sweet lupine laddoo, an important parameter for consumer acceptance, showed no significant difference between sweet lupine supplemented laddoo and control, except for $100 \%$ sweet lupine laddoo. For color and appearance, $75 \%$ sweet lupine laddoo also recorded higher scores. There was no significant difference in hardness between control and sweet lupine supplemented laddoo, except for $100 \%$ sweet lupine laddoo which scored lower. Our results are in contrast with work by Indu and Awasthi (2018) who prepared laddoos from variations of the cereal-legume blend.

Table (1): Sensory evaluation of wheat laddoo fortified with sweet lupine

\begin{tabular}{|c|c|c|c|c|c|}
\hline Properties & $\mathbf{1 0 0 \%}$ Wheat & $\mathbf{2 5 \%}$ Sweet Lupine & $\mathbf{5 0 \%}$ Sweet Lupine & $\begin{array}{c}\mathbf{7 5 \%}^{\text {Sweet }} \\
\text { Lupine }\end{array}$ & $\begin{array}{c}\text { 100\% Sweet } \\
\text { Lupine }\end{array}$ \\
\hline Color (9) & $8.00 \pm 0.02^{\mathrm{c}}$ & $8.00 \pm 0.07^{\mathrm{c}}$ & $8.35 \pm 0.17^{\mathrm{b}}$ & $8.50 \pm 0.05^{\mathrm{a}}$ & $8.30 \pm 0.03^{\mathrm{b}}$ \\
\hline Appearance (9) & $8.00 \pm 0.05^{\mathrm{b}}$ & $8.00 \pm 0.11^{\mathrm{b}}$ & $8.30 \pm 0.02^{\mathrm{a}}$ & $8.30 \pm 0.17^{\mathrm{a}}$ & $8.00 \pm 0.07^{\mathrm{b}}$ \\
\hline Aroma (9) & $8.30 \pm 0.03^{\mathrm{b}}$ & $8.30 \pm 0.17^{\mathrm{b}}$ & $8.32 \pm 0.11^{\mathrm{b}}$ & $8.50 \pm 0.07^{\mathrm{a}}$ & $8.00 \pm 0.02^{\mathrm{c}}$ \\
\hline Hardness (9) & $8.50 \pm 0.07^{\mathrm{a}}$ & $8.50 \pm 0.02^{\mathrm{a}}$ & $8.53 \pm 0.05^{\mathrm{a}}$ & $8.55 \pm 0.03^{\mathrm{a}}$ & $8.00 \pm 0.11^{\mathrm{b}}$ \\
\hline Flavor (9) & $8.50 \pm 0.11^{\mathrm{a}}$ & $8.48 \pm 0.07^{\mathrm{a}}$ & $8.50 \pm 0.13^{\mathrm{a}}$ & $8.50 \pm 0.15^{\mathrm{a}}$ & $8.00 \pm 0.13^{\mathrm{b}}$ \\
\hline Mouth feel (9) & $8.10 \pm 0.17^{\mathrm{c}}$ & $8.15 \pm 0.13^{\mathrm{c}}$ & $8.25 \pm 0.07^{\mathrm{b}}$ & $8.56 \pm 0.11^{\mathrm{a}}$ & $8.10 \pm 0.05^{\mathrm{c}}$ \\
\hline Overall acceptability (9) & $8.80 \pm 0.13^{\mathrm{a}}$ & $8.53 \pm 0.05^{\mathrm{b}}$ & $8.57 \pm 0.03^{\mathrm{b}}$ & $8.80 \pm 0.02^{\mathrm{a}}$ & $8.42 \pm 0.17^{\mathrm{c}}$ \\
\hline
\end{tabular}

Values are means of ten replicates \pm SD. Values number in the same raw followed by the same letter are not significantly different at 0.05 levels.

\section{Chemical composition of raw materials and laddoo products}

Table (2), showed that the chemical composition of raw materials and different products from the laddoo.
From the results, it could be noticed that the increase in sweet lupine powder caused an increase in moisture content, $14.16 \%$ for control to $15.06 \%$ for $100 \%$ sweet lupine laddoo. This increase in moisture may be due to the 
high water holding capacity (WHC) of sweet lupine powder. Sweet lupine flour had a high WHC (256.63\%). Results of WHC of sweet lupine, they agree with work by Mahmoud et al. (2012) and Cano and Ancos (2005) found that proteins forming a three-dimensional network structure to provide a matrix capable of holding high amounts of water in sweet lupine flour.

As expected, the increase in lupin powder resulted in a significant increase in protein, the protein content increased from 5.74, of control, to $24.05 \%$ for $100 \%$ sweet lupine laddoo. These increase in due to the high protein content of lupin $(32.37 \mathrm{gm} / 100 \mathrm{gm})$. This agrees with work by Ahmed, 2019. As for fat content, it increased from $21.68 \%$ for control to $26.15 \%$ for laddoo with $100 \%$ sweet lupine. An increase in fat may result from the high-fat content of sweet lupine $(3.18 \%)$. The oil holding capacity of sweet lupine powder was 110.85\%. Algarni et al. (2019) urged that the raised oil absorption of the sweet lupine flour is also because of the lipophilic nature of sweet lupin seed proteins. The presence of many non-polar side chains could bind the hydrocarbon chains of fats, thereby leading to higher absorption of oil. The mechanism of fat absorption is attributed principally to the physical entrapment of oil and also the binding of fat to the polar chain of the protein. Ash, fiber, and carotenes also increase with increasing the level of sweet lupine in laddoo. This may be due to the high level of ash, fiber, and carotene in sweet lupine. It could be concluded that the increase in sweet lupine powder caused an increase in all measured parameters, except for carbohydrates.

Table (2): Chemical Composition of both Ingredients and Produced Laddoo

\begin{tabular}{|c|c|c|c|c|c|c|c|c|}
\hline Ingredients & Moisture & Protein & Fat & Ash & Fiber & Carbohydrate & Carotene \\
\hline \multicolumn{7}{|c|}{} \\
\hline Wheat Flour & $11.90 \pm 0.04$ & $10.01 \pm 0.05$ & $0.95 \pm 0.03$ & $0.49 \pm 0.01$ & $0.47 \pm 0.01$ & $87.44 \pm 0.53$ & $\mathrm{Nd}^{*}$ \\
\hline Sweet Lupine Flour & $8.40 \pm 0.12$ & $32.37 \pm 0.10$ & $3.18 \pm 0.04$ & $1.25 \pm 0.07$ & $4.99 \pm 0.15$ & $51.43 \pm 0.23$ & 2.7 \\
\hline \multicolumn{7}{|c|}{ Produced Laddoo } \\
\hline Control & $14.16 \pm 0.03^{\mathrm{e}}$ & $5.74 \pm 0.07^{\mathrm{e}}$ & $21.68 \pm 0.11$ & $0.15 \pm 0.07^{\mathrm{e}}$ & $0.69 \pm 0.03^{\mathrm{e}}$ & $72.58 \pm 0.13^{\mathrm{a}}$ & $\mathrm{Nd}^{\mathrm{a}}$ \\
\hline $\mathbf{2 5 . 0 \%}$ & $14.39 \pm 0.13^{\mathrm{d}}$ & $11.40 \pm 0.11^{\mathrm{d}}$ & $23.80 \pm 0.09$ & $0.54 \pm 0.09^{\mathrm{d}}$ & $1.10 \pm 0.05^{\mathrm{d}}$ & $64.80 \pm 0.11^{\mathrm{b}}$ & $0.49 \pm 0.03^{\mathrm{d}}$ \\
\hline $\mathbf{5 0 . 0 \%}$ & $14.61 \pm 0.19^{\mathrm{c}}$ & $16.20 \pm 0.05^{\mathrm{c}}$ & $24.50 \pm 0.17$ & $0.77 \pm 0.10^{\mathrm{c}}$ & $1.63 \pm 0.11^{\mathrm{c}}$ & $59.30 \pm 0.07^{\mathrm{c}}$ & $0.99 \pm 0.05^{\mathrm{c}}$ \\
\hline $\mathbf{7 5 . 0 \%}$ & $14.83 \pm 0.11^{\mathrm{b}}$ & $19.83 \pm 0.11^{\mathrm{b}}$ & $25.39 \pm 0.15$ & $1.00 \pm 0.15^{\mathrm{b}}$ & $2.56 \pm 0.10^{\mathrm{b}}$ & $54.78 \pm 0.11^{\mathrm{d}}$ & $1.49 \pm 0.09^{\mathrm{b}}$ \\
\hline $\mathbf{1 0 0 \%}$ & $15.06 \pm 0.15^{\mathrm{a}}$ & $24.05 \pm 0.09^{\mathrm{a}}$ & $26.15 \pm 0.13^{\mathrm{a}}$ & $1.09 . \pm 0.07^{\mathrm{a}}$ & $3.50 \pm 0.04^{\mathrm{a}}$ & $49.80 \pm 0.03^{\mathrm{e}}$ & $1.97 \pm 0.15^{\mathrm{a}}$ \\
\hline
\end{tabular}

*ND: Not detected

Values are means of three replicates \pm SD. Values number in the same raw followed by the same letter are not significantly different at 0.05 levels.

\section{Minerals content of wheat laddoo fortified with sweet lupine}

Table (3) showed that the mineral content of both ingredients and different products from the laddoo. The results illustrated that the minerals content of sweet lupine is high, making it a good source of minerals. The mineral content of sweet lupine is slightly below those reported by Suliburska et al. (2008). The variation in chemical composition could be attributed to variations in variety and different growing conditions (such as geographic, variations because of the season climatic conditions and soil characteristics), and extent of foreign materials, impurities, varieties, different method and measuring ways as reported by Taher-Maddah $\boldsymbol{e t}$ al. (2012).

It could be noticed that the increase in sweet lupine powder caused an increase in all measured minerals. The increase in mineral contents of supplemented products might be due to high contents of calcium, phosphorus, magnesium and zinc in sweet lupine flour as compared to wheat flour. Our results are in contrast with work by Pandey and Sangwan (2019) who reported an increase in mineral content of laddoo with the addition of soybean and sorghum flour. Also, calcium showed a $74.05 \%$ increase, while iron and zinc were more than 3 and 5 times their content in control.

Table (3): Mineral content of wheat laddoo fortified with sweet lupine

\begin{tabular}{|c|c|c|c|c|c|c|c|c|c|}
\hline $\begin{array}{c}\text { Sample } \\
\text { (mg/100 g) }\end{array}$ & Calcium & Phosphorous & Magnesium & Iron & Zinc & Copper & \multicolumn{2}{c|}{ Sodium } & Potassium \\
\hline \multicolumn{7}{|c|}{ Ingredients } \\
\hline Wheat flour & $15.00 \pm 0.02$ & $108.0 \pm 0.08$ & $22.00 \pm 0.04$ & $1.17 \pm 0.03$ & $0.70 \pm 0.02$ & $0.14 \pm 0.08$ & $2.00 \pm 0.02$ & $107.00 \pm 0.04$ \\
\hline Sweet Lupine & $190.30 \pm 0.05$ & $410.00 \pm 0.11$ & $122.56 \pm 0.14$ & $4.33 \pm 0.07$ & $3.19 \pm 0.04$ & $0.70 \pm 0.01$ & $5.00 \pm 0.06$ & $950.00 \pm 0.18$ \\
\hline \multicolumn{7}{|c|}{ Products } \\
\hline $\mathbf{1 0 0 \% \text { Wheat }}$ & $6.01 \pm 0.01^{\mathrm{e}}$ & $28.24 \pm 0.03^{\mathrm{e}}$ & $6.46 \pm 0.05^{\mathrm{e}}$ & $0.32 \pm 0.17^{\mathrm{e}}$ & $0.21 \pm 0.07^{\mathrm{e}}$ & $3.61 \pm 0.51^{\mathrm{d}}$ & $3.61 \pm 0.04^{\mathrm{e}}$ & $27.95 \pm 0.06^{\mathrm{e}}$ \\
\hline $\begin{array}{c}\mathbf{2 5 \%} \text { Sweet } \\
\text { Lupine }\end{array}$ & $17.13 \pm 0.08^{\mathrm{d}}$ & $47.42 \pm 0.01^{\mathrm{d}}$ & $12.84 \pm 0.04^{\mathrm{d}}$ & $0.52 \pm 0.17^{\mathrm{d}}$ & $0.40 \pm 0.07^{\mathrm{d}}$ & $3.80 \pm 0.05^{\mathrm{cd}}$ & $3.81 \pm 0.61^{\mathrm{d}}$ & $81.45 \pm 0.06^{\mathrm{d}}$ \\
\hline $\begin{array}{c}\mathbf{5 0 \%} \text { Sweet } \\
\text { Lupine }\end{array}$ & $28.24 \pm 0.04^{\mathrm{c}}$ & $66.56 \pm 0.05^{\mathrm{c}}$ & $19.23 \pm 0.02^{\mathrm{c}}$ & $0.72 \pm 0.07^{\mathrm{c}}$ & $0.61 \pm 0.05^{\mathrm{c}}$ & $4.00 \pm 0.01^{\mathrm{b}}$ & $4.00 \pm 0.06^{\mathrm{c}}$ & $134.95 \pm 0.08^{\mathrm{c}}$ \\
\hline $\begin{array}{c}\mathbf{7 5 \%} \text { Sweet } \\
\text { Lupine }\end{array}$ & $39.41 \pm 0.03^{\mathrm{b}}$ & $85.74 \pm 0.03^{\mathrm{b}}$ & $25.62 \pm 0.02^{\mathrm{b}}$ & $0.92 \pm 0.11^{\mathrm{b}}$ & $0.81 \pm 0.05^{\mathrm{b}}$ & $4.16 \pm 0.05^{\mathrm{b}}$ & $4.16 \pm 0.04^{\mathrm{b}}$ & $188.45 \pm 0.08^{\mathrm{b}}$ \\
\hline $\begin{array}{c}\mathbf{1 0 0 \%} \text { Sweet } \\
\text { Lupine }\end{array}$ & $50.52 \pm 0.10^{\mathrm{a}}$ & $104.91 \pm 0.01^{\mathrm{a}}$ & $32.01 \pm 0.01^{\mathrm{a}}$ & $1.12 \pm 0.02^{\mathrm{a}}$ & $1.02 \pm 0.03^{\mathrm{a}}$ & $4.35 \pm 0.04^{\mathrm{a}}$ & $4.35 \pm 0.09^{\mathrm{a}}$ & $241.95 \pm 0.05^{\mathrm{a}}$ \\
\hline
\end{tabular}

Values are means of three replicates \pm SD. Values number in the same raw followed by the same letter are not significantly different at 0.05 levels. 


\section{Vitamins content of raw materials and laddoo products}

Vitamins content was determined in raw materials and different products from the laddoo and the results are reported in Table (4). Vitamins content of sweet lupine is elevated, making it a good source of vitamins. These results agree with those reported by Erbas et al. (2005) and Frias et al. (2005). Moreover, it could be noticed that the addition of sweet lupine powder caused an increase in all measured vitamins. The increase in the vitamin content of supplemented products might be due to high vitamin content in sweet lupine flour as compared to wheat flour. Vitamin A increased for $100 \%$ sweet lupine flour laddoo to reach 1.97. Vitamin B group showed the highest increase due to the high vitamin $\mathrm{B}$ content in sweet lupin.

Table (4): Vitamin Content of raw materials and laddoo products

\begin{tabular}{|c|c|c|c|c|c|c|c|c|c|}
\hline $\begin{array}{c}\text { Sample } \\
(\mathrm{mg} / 100 \mathrm{~g})\end{array}$ & $\begin{array}{c}\text { Vitamin A } \\
(\mathbf{R E})\end{array}$ & $\begin{array}{l}\text { Thiamin } \\
\text { (mg) B1 }\end{array}$ & $\begin{array}{c}\text { Riboflavin } \\
\text { (mcg) B2 }\end{array}$ & \begin{tabular}{|c} 
Niacin $(\mathrm{mcg})$ \\
B3
\end{tabular} & Vitamin B6 & $\begin{array}{c}\text { Folate } \\
\text { (ug) B9 }\end{array}$ & $\begin{array}{c}\text { Vitamin B12 } \\
(\mathrm{mcg})\end{array}$ & $\begin{array}{c}\text { Vitamin } \mathbf{C} \\
(\mathrm{mg})\end{array}$ & Vitamin $\mathbf{E}$ \\
\hline \multicolumn{10}{|c|}{ Ingredient } \\
\hline Wheat flour & $\mathrm{Nd}$ & 0.090 .02 & $0.04 \pm 0.01$ & $1.13 \pm 0.05$ & $0.04 \pm 0.03$ & $18.20 \pm 0.04$ & 0.00 & 0.00 & $0.06 \pm 0.02$ \\
\hline Sweet Lupine & $7.77 \pm 0.03$ & $0.32 \pm 0.04$ & $0.59 \pm 0.05$ & $3.90 \pm 0.03$ & $0.40 \pm 0.05$ & $40.00 \pm 0.02$ & 0.00 & 0.00 & $1.10 \pm 0.01$ \\
\hline \multicolumn{10}{|c|}{$\begin{array}{l}\text { Products } \\
\end{array}$} \\
\hline $100 \%$ Wheat & $\mathrm{Nd}$ & $0.02 \pm 0.01^{\mathrm{e}}$ & $0.02 \pm 0.01^{\mathrm{e}}$ & $0.29 \pm 0.05^{\mathrm{e}}$ & $0.01 \pm 0.02^{\mathrm{e}}$ & $4.62 \pm 0.03^{\mathrm{e}}$ & 0.00 & 0.00 & $4.28 \pm 0.03^{\mathrm{e}}$ \\
\hline $\begin{array}{c}25 \% \text { Sweet } \\
\text { Lupine }\end{array}$ & $0.65 \pm 0.01^{d}$ & $0.03 \pm 0.05^{\mathrm{d}}$ & $0.05 \pm 0.03^{d}$ & $0.45 \pm 0.02^{\mathrm{d}}$ & $0.03 \pm 0.04^{\mathrm{d}}$ & $5.88 \pm 0.01^{\mathrm{d}}$ & 0.00 & 0.00 & $4.35 \pm 0.06^{\mathrm{d}}$ \\
\hline $\begin{array}{c}50 \% \text { Sweet } \\
\text { Lupine }\end{array}$ & $1.30 \pm 0.06^{\mathrm{c}}$ & $0.05 \pm 0.02^{\mathrm{c}}$ & $0.08 \pm 0.01^{\mathrm{c}}$ & $0.61 \pm 0.04^{\mathrm{c}}$ & $0.05 \pm 0.02^{c}$ & $7.13 \pm 0.05^{\mathrm{c}}$ & 0.00 & 0.00 & $4.41 \pm 0.09^{\mathrm{c}}$ \\
\hline $\begin{array}{c}75 \% \text { Sweet } \\
\text { Lupine }\end{array}$ & $1.95 \pm 0.09^{b}$ & $0.06 \pm 0.03^{b}$ & $0.12 \pm 0.02^{\mathrm{b}}$ & $0.78 \pm 0.07^{\mathrm{b}}$ & $0.08 \pm 0.05^{\mathrm{b}}$ & $8.39 \pm 0.04^{\mathrm{b}}$ & 0.00 & 0.00 & $4.48 \pm 0.04^{b}$ \\
\hline $\begin{array}{l}\text { 100\% Sweet } \\
\text { Lupine }\end{array}$ & $2.59 \pm 0.04^{\mathrm{a}}$ & $0.08 \pm 0.04^{\mathrm{a}}$ & $0.16 \pm 0.06^{\mathrm{a}}$ & $1.00 \pm 0.09^{\mathrm{a}}$ & $0.10 \pm 0.01^{\mathrm{a}}$ & $10.15 \pm 0.06^{\mathrm{a}}$ & 0.00 & 0.00 & $4.54 \pm 0.05^{\mathrm{a}}$ \\
\hline
\end{tabular}

Values are means of three replicates \pm SD. Values number in the same raw followed by the same letter are not significantly different at 0.05 levels.

\section{Nutritional evaluation of laddoo products}

The percentages of the recommended dietary allowances (\% RDA) are provided from $100 \mathrm{~g}$ of laddoo for males and females are shown in tables -5 and 6-. As expected, the addition of sweet lupine flour raised the nutritional value of the produced laddoos. Laddoos fortified with $75 \%$ sweet lupine provide males with $35.41 \%$ protein, $6.74 \%$ fiber. Also, 100gm sweet lupine fortified laddoos provide males with substantial amounts of vitamins. While fortified laddoos provide $3.94 \%$ of daily requirements of calcium, $11.50 \%$ of iron requirements and $7.36 \%$ of zinc daily requirements.

Table 5: Nutritional evaluation of wheat laddoo fortified with sweet lupine for male 19-70 years

\begin{tabular}{|c|c|c|c|c|c|}
\hline Nutritional composition & $\mathbf{1 0 0 \%}$ Wheat & $\mathbf{2 5 \%}$ Sweet Lupine & $\mathbf{5 0 \%}$ Sweet Lupine & $\begin{array}{c}\mathbf{7 5 \%} \text { Sweet } \\
\text { Lupine }\end{array}$ & $\begin{array}{c}\mathbf{1 0 0 \%} \text { Sweet } \\
\text { Lupine }\end{array}$ \\
\hline Protein (56g/d) & 10.25 & 20.36 & 28.93 & 35.41 & 42.95 \\
\hline Fiber (38g/d) & 1.82 & 2.89 & 4.29 & 6.74 & 9.21 \\
\hline Vit A (625 ug/d) & - & 0.11 & 0. & 0.24 & 0.32 \\
\hline Thiamin (1mg/d) & 2.00 & 3.00 & 5.00 & 6.00 & 8.00 \\
\hline Riboflavin (1.1 mg/d) & 1.82 & 4.55 & 7.27 & 10.91 & 14.55 \\
\hline Niacin (12mg/d) & 2.42 & 3.75 & 5.08 & 6.50 & 8.33 \\
\hline Folate (400mg/d) & 1.16 & 1.47 & 1.78 & 2.10 & 2.54 \\
\hline Ca (1000mg/d) & 0.60 & 1.71 & 2.82 & 3.94 & 5.05 \\
\hline Fe (8mg/d) & 4.00 & 6.50 & 9.00 & 11.5 & 14.00 \\
\hline Zn (11mg/d) & 1.91 & 3.60 & 5.55 & 7.36 & 9.27 \\
\hline
\end{tabular}

But for females, Laddoos fortified with $75 \%$ sweet lupine provide them with $43.11 \%$ protein, 10.24 and $12.19 \%$ fiber form females $19-50$ and $51-70$ years respectively. Also, 100gm sweet lupine fortified laddoos provide females with substantial amounts of vitamins. While fortified laddoos provide 3.94 and $3.28 \%$ of daily requirements of calcium, 5.11 and $11.5 \%$ of iron requirements and $10.13 \%$ of zinc daily requirements.

It could be noticed that consuming fortified laddoos could provide males and females with part of their daily requirements of protein, dietary fiber, vitamins, calcium, iron and zinc.

Table 6: Nutritional Evaluation of Wheat Laddoo Fortified with Sweet Lupine for Females 19-50 years

\begin{tabular}{|c|c|c|c|c|c|}
\hline Nutritional composition & $\begin{array}{l}100 \% \\
\text { Wheat }\end{array}$ & $\begin{array}{l}25 \% \text { Sweet } \\
\text { Lupine }\end{array}$ & $\begin{array}{ll}50 \% & \text { Sweet } \\
\text { Lupine } & \\
\end{array}$ & $\begin{array}{ll}75 \% & \text { Sweet } \\
\text { Lupine } & \\
\end{array}$ & $\begin{array}{l}100 \% \text { Sweet } \\
\text { Lupine }\end{array}$ \\
\hline \multicolumn{6}{|l|}{ Female 19-50 } \\
\hline Protein $(46 \mathrm{~g} / \mathrm{d})$ & 12.48 & 24.78 & 35.22 & 43.11 & 52.28 \\
\hline Fiber $(25 \mathrm{~g} / \mathrm{d})$ & 2.76 & 4.4 & 6.52 & 10.24 & 14.00 \\
\hline Vit A $(700 \mu \mathrm{g} / \mathrm{d})$ & - & & & & \\
\hline Thiamin (1.1mg/d) & 1.82 & 2.73 & 4.55 & 5.45 & 7.27 \\
\hline Riboflavin (1.1 mg/d) & 1.82 & 4.55 & 7.27 & 10.91 & 14.55 \\
\hline Niacin $(14 \mathrm{mg} / \mathrm{d})$ & 2.07 & 3.21 & 4.36 & 5.57 & 7.14 \\
\hline
\end{tabular}




\begin{tabular}{|l|l|l|l|l|l|}
\hline Ca (1000mg/d) & 0.60 & 1.71 & 2.82 & 3.94 & 5.05 \\
\hline Fe (18mg/d) & 1.77 & 2.89 & 4.00 & 5.11 & 6.22 \\
\hline Zn (8mg/d) & 2.63 & 5.00 & 7.63 & 10.13 & 12.75 \\
\hline Female 51-70 & 12.48 & 24.78 & 35.22 & 43.11 & 52.28 \\
\hline Protein (46g/d) & 1.82 & 2.73 & 4.55 & 12.19 & 16.67 \\
\hline Fiber (21g/d) & - & & & \\
\hline Vit A (700 $\mu$ g/d) & 1.82 & 2.73 & 4.55 & 5.45 & 7.27 \\
\hline Thiamin (1.1mg/d) & 1.82 & 4.55 & 7.27 & 10.91 & 14.55 \\
\hline Riboflavin (1.1 mg/d) & 2.07 & 3.21 & 4.36 & 5.57 & 7.14 \\
\hline Niacin (14mg/d) & 0.50 & 1.43 & 2.35 & 3.28 & 4.21 \\
\hline Ca (1200mg/d) & 4.00 & 6.50 & 9.00 & 11.50 & 14.00 \\
\hline Fe (8mg/d) & 2.63 & 5.00 & 7.63 & 10.13 & 12.75 \\
\hline Zn (8mg/d)
\end{tabular}

\section{CONCLUSION}

Nutritious laddoo fortified with sweet lupines a product providing a variety of nutrients like protein, fiber, calcium, vitamins, iron, minerals, etc., and can be recommended for all age groups. Thus it could be recommended that the addition of sweet lupine until $75 \%$ to give laddoo is nutritionally and acceptable in comparison to $100 \%$ wheat flour laddoo.

\section{REFERENCES}

[1] Ahmed, A.R.A. (2012). Technological and Nutritional Studies on Sweet Lupine Seeds and its Applicability in Selected Bakery Products. Ph.D. Technical University of Berlin

[2] AOAC. (2012). Official methods of analysis, $19^{\text {th }}$ edition Association of Official Analytical Chemists. Washington DC.

[3] Algarni, E.H., Hussien, H.A. and Salem, E.M. (2019). Development of Nutritious Extruded Snacks. Life Science Journal, 16(9)

[4] Arnoldi, A. (2008). Nutraceutical properties of white and narrowleaved lupin. In Proceedings of the $12^{\text {th }}$ International Lupin Conference, Fremantle, Western Australia (J.A. Palta and J.D. Berger, eds) International Lupin Association, Canterbury, New Zealand.

[5] Baker, R. (2006). A sweet traditional Hejazi Treats. Arab News (accessed 22 August 2014).

[6] Batifoulier, F.;Verny, M. A.;Besson, C.;Demigne, C. and Remesy, C. (2005). Journal of Chromatography B, 816:67-72.

[7] Botaro, J.A. (2010). Optimization for Obtaining Aqueous Extract of White Lupine (L. Lupinusalbus) Added of Cherry Juice. 101f. Dissertação (Mestrado em Alimentos e Nutrição), Faculdade de Ciências Farmacêuticas UNESP, São Paulo.

[8] Cano, M.P., Ancos, B. (2005). Advances in use of high pressure to processing and preservation of plant. In: Barbosa-Ca'novas, G.V., Tapia, M.S., Cano, M.P. (Eds.), Novel Food Processing Technologies. CRC Press, New York, USA. p. 291

[9] Chetana, R. (2004). Studies on the use of sucrose alternatives in traditional sweetmeats, $\mathrm{PhD}$ thesis, The University of Mysore, Mysore

[10] Diaz, J.M.R; Sundarrajan, L.; Kariluoto, S.; Lampi, A.M.; Tenitz, S. and Jouppila, K. (2017). Partial least squares regression modeling of physical and chemical properties of cornbased snacks containing kaniwa and lupine. Journal of Food Processing and Preservation. 40, 1-15.

[11] Erbas, M.; Certel, M. and Uslu, M.K. (2005). Some chemical properties of white lupin seeds (Lupinus albus L.), Food Chemistry $89,341-345$.

[12] Food and Nutrition Board, Institute of Medicine, \& National Academies. (2004). Dietary Reference Intakes (DRIs).

[13] Frias, J.; Miranda, M. L.; Doblado, R. and Vidal-Valverde, C. (2005). Effect of germination and fermentation on the antioxidant vitamin content and antioxidant capacity of Lupinus albus L. var. Multolupa. Food Chemistry, 92, 211-220

[14] Ghatge, N.S. (2013).Clinical nutritional status of malnourished pre-school children after supplementation of soy laddoo,
Research Journal of Family, Community Consumer Sciences, 1(3), 18-24.

[15] Ghavidel, R.A. and Prakash, J. (2007), "The impact of germination and de-hulling on nutrients, anti-nutrients in vitro iron and calcium bioavailability and in vitro starch and protein digestibility of some legume seeds", LWT-Food Science and Technology, 40(7), 1292-1299.

[16] Hall, R.S., Johnson, S., Baxter, A. and Ball, M. (2005). Lupin kernel fibre-enriched foods beneficially modify serum lipids in men. Eur. J. Clin. Nutr.; 59, 325-333.

[17] James, C.S. (1995) General Food Studies. In: Analytical Chemistry of Foods, Blachie Academic and Professional, London, New York, Tokyo.; Chapter 6, p 135.

[18] Lee, Y.P., Mori, T.A., Puddey, I.B., Sipsas, S., Ackland, T.R. Beilin, L.J. and Hodgson, J.M. (2009). Effects of lupin kerne flour-enriched bread on blood pressure: A controlled intervention study. Am. J. Clin.Nutr.; 89, 766-772.

[19] Monteiro, M.R.P., Oliveira, C.T., Silva, L.S., Mendes, F.Q. and Sant'ana, R.C.O. (2010). Effect of Heat Treatment on Digestibility, Solubility and Urease Activity Index in Lupine (Lupinus albus e Lupinus angultifolius). Alim. Nutr.; 21, $487-$ 493

[20] Naidu, B.G., Shirke, K.J. and Shekhar, A. (2013). A study of a galactogouge and protein rich -multigrain laddoo, International Journal of Food and Nutritional Sciences, 2 (2), 91-94.

[21] Noll, G. N. (1996). High-performance liquid chromatographic analysis of retinal and retinol isomers. Journal of Chromatography A., 721:247-259.

[22] Pandey, L. and Sangwan, V. (2019). Mineral characteristics and shelf life studies of cereal and legume based value added Ladoos. International Journal of Chemical Studies; 7(1): 14-19.

[23] Pyka, A. and Sliwiok, J. (2001). Chromatographic separation of tocopherols. Journal of Chromatography A, $935: 71-76$.

[24] Rana, S., Sharma, S., Katare, C., Shrivatava, V. and Prasad, G.K.B.S. (2012), "Glycemic response and glycemic index of common sweeteners and honey incorporated products", IOSR Journal of Nursing Health Science, Vol. 1 No. 1, pp. 40-44.

[25] Santra, M., Rao, V.S. and Tamhankar, S.A. (2003) Modification of AACC procedure for measuring $\beta$-carotene in early generation durum wheat. Cereal Chem.; 80(2): 130-131.

[26] Sirtori, C.R., Lovati, M.R., Manzoni, C., Castiglioni, S., Duranti, M., Magni, C., Morandi, S., D’Agostina, A. and Arnoldi, A. (2004). Proteins of white lupin seed, a naturally isoflavone-poor legume, reduce cholesterolemia in rats and increase LDL receptor activity in HepG2 cells. J. Nutr.; 134, 18 23.

[27] Suliburska, J., Krejpcio, Z., Lampart-Szczapa, E., and Wójciak, R. W. (2009). Effect of fermentation and extrusion on the release of selected minerals from lupine grain preparations. Acta Sci. Pol., Technol. Aliment; 8(3), 87-96.

[28] "Sweet shops make hay in Diwali shine". The New Indian Express. 2013-10-31. Retrieved 2019-01-17.

[29] Taher-Maddah, M., Maheri-Sos, N., Salamatdoustnobar, R. and Ahmadzadeh, A. (2012). Comparing nutritive value of ensiled and dried pomegranate peels for ruminants using in vitro gas production technique. Ann. Biolog. Res. 3(4): 1942-1946. 
[30] Teba, C.S., Ascheri, J.L.R. and Carvalho, C.W.P. (2009). Effect of Extrusion on Pasting Properties of Pre-Cooked Rice Noodles and Bean Parameters. Alim. Nutr., 20, 411-426.

[31] Verma, A., Neeru, B., Shukla, M. and Sheikh, S. (2014) Preparation of low cost snacks by incorporation of developed flour mixtures, International Research Journal of Pharmaceuticals and Applied Sciences, 4(1), 61-63.

[32] Wandersleben, T., Morales, E., Burgos-Díaz, C., Barahona, T., Labra, E., Rubilar, M. and Salvo-Garrido, H. (2018). Enhancement of functional and nutritional properties of bread using a mix of natural ingredients from novel varieties of flaxseed and lupine. LWT. 91, 48-54. 